\title{
DEFICIT IRRIGATION AT DIFFERENT GROWTH STAGES OF THE COMMON BEAN (Phaseolus vulgaris L., cv. IMBABELLO)
}

\author{
M. CALVACHE'; K. REICHARDT ${ }^{23,5} ;$ O.O.S. BACCH ${ }^{3,3}$; D. DOURADO-NETO ${ }^{4,5}$ \\ 'Universidad Central del Ecuador, P.O. Box 2520 - Quito - Ecuador. \\ ${ }^{2}$ Centro de Energia Nuclear na AgriculturaUSP, C.P. 96, CEP: 13416-970 - Piracicaba, SP - Brazil. \\ 'Depto. de Física-ESALQUSP, C.P. 9, CEP: 13418-900 - Piracicaba, SP-Brazil. \\ 'Depto. de Agricultura-ESALQUSP, C.P. 9, CEP: 13418-900 - Piracicaba, SP-Brazil. \\ 'Bolsista do CNPQ.
}

\begin{abstract}
To identify specific growth stages of the common bean crop at which the plant is less sensitive to water stress, in which irrigation could be omitted without significant decrease in final yleld, two field experiments were conducted at "La Tola" University Experimental Station, Tumbaco, Pichincha, Ecuador, on a sandy loam soll (Typic Haplustoll). The climate is tempered and $\mathrm{dry}$ (mean air temperature $16^{\circ} \mathrm{C}$ and mean relative humidity $74 \%$, during the cropping season) 123 and $109 \mathrm{~mm}$ of rainfall were recorded during the experimental cropping periods (July to October), of 1992 and 1994, respectively. The treatments consisted of combinations of 7 irrigation regimes inciuding normal watering; full stress; (traditional management practice); single stress at vegetative stage; flowering; seed formation and ripening, and of 2 levels of applied $N(20$ and $80 \mathrm{~kg} / \mathrm{ha}$ ). These 14 treatment combinations were arranged and analysed in a split-plot design with 4 replications. The plot size was $33.6 \mathrm{~m}^{2}(8 \mathrm{rows}, 7 \mathrm{~m}$ long) with a plant population of $120,000 \mathrm{pl} / \mathrm{ha}$. Irrigation treatments were started after uniform germination and crop establishment. Soll water content was monitored with a neutron probe down to $0.50 \mathrm{~m}$ depth, before and $24 \mathrm{~h}$ after each irrigation. The actual evapotranspiration of the crop was estimated by the water-balance technique. Field water efficiency and crop water use efficiency were calculated. Yield data showed that the treatments which had irrigation deficit had lower yield than those that had supplementary irrigation. The flowering stage was the most sensitive to water stress. Nitrogen fertlization significantly increased the number of pods and grain yield. Crop water use eficlency $\left(\mathrm{gg}^{3}\right)$ was the lowest with stress at the flowering period, and the yield response factor (Ky) was higher in treatments of full stress and stress at flowering. In relation to the traditional management practice adopted by farmers, only treatments of normal watering and stress at maturation had 13 and $10 \%$ higher crop water use eficiency, respectively.
\end{abstract}

Key Words: common bean, irrigation, water stress, water use eficiency

\section{DEFICIÊNCIA DE ÁGUA EM DIFERENTES ESTÁDIOS DE DESENVOLVIMENTO DO FEIJOEIRO (Phaseolus vulgaris L, cv. IMBABELLO)}

RESUMO: Com o objetivo de Identificar estádios especificos de desenvolvimento do feijoeiro, nos quais a planta é menos sensivel ł deficiência de água e a irrigạảo poderia ser suprimida sem decréscimo significativo em produtividade, dois experimentos de campo foram conduzidos na Estaçåo Experimental "La Tola", pertencente à Universidade Central de Equador, em Tumbaco, Pichincha, Equador. Os tratamentos consistiram de combinaçōes de sete regimes de irrigaç̃o, incluindo a irrigaçăo normal, deficiêncla completa, prótica de manejo tradicional, deficiência no período vegetativo, deficiência na floração, deficiência na formaçāo de vagens e deficiência no enchimento de grăos, e de dois niveis de fertllizante nitrogenado, 20 e $80 \mathrm{~kg} / \mathrm{ha}$. Essas quatorze combinaçóes de tratamentos foram organizadas e anallsadas segundo um delineamento estatístico de parcelas sub-divididas, com quatro repetiç̄es. As parcelas foram de $33,6 \mathrm{~m}^{2}$ (8 linhas de $7 \mathrm{~m}$ de comprimento, com uma populaç̃o de $120.000 \mathrm{pl} /$ ha. Os tratamentos de irrigaça iniclaram-se após a germinaç̄o uniforme e estahelecimento da cultura. O conteúdo de água do solo fol monitorada com sonda de nêutrons até a profundidade de $0,5 \mathrm{~m}$, antes e 24 h após cada irrigaçăo. A evapotranspiracão atual da cultura fol estimada pelo balanco hídrico. Calculon-se as eficiências de uso de áqua no campo e pela cultura. Dados de produthvilade mostram que os tratamentos que tiveram deficiências apresentaram menor produtividade em relação a tratamentos com imigaço complementar. $O$ estádio do floresci-mento fol o mais sensivel à deficiência de água. $A$ fertilizaçĭo com $\mathrm{N}$ aumentou significativamente o número de vagens por planta e a produção de sementes. $A$ eficiência de uso de água pela cultura $\left(\mathrm{kg}_{\mathrm{g}} \mathrm{m}^{\prime}\right)$ fol menor com deficiência na noraçăo, e o fator de resposta à produtividade (ke) fol maior nos tratamentos de deficiência total e deficiência no forescimento. Considerando as príticas tradicionais de manejo utilizadas pelos agricultores, apenas os tratamentos de irrigaç̧o normal e de deficiência na maturaçă, tiveram uma eficiência de uso de água de 13 e $10 \%$ maior, respectivamente.

Descritores: feijjāo comum, irrigaçăo, deficiência de água, eficiência de uso de água 


\section{INTRODUCTION}

In Ecuador, the bean crop (Phaseolus vulgaris L.) is generally cultivated under rainfed conditions, in marginal lands in the semi-arid higlands $(1800-3000 \mathrm{~m})$. Water stress is a very common problem during the growing period, exacerbated by the fact that the crop is planted in shallow soils with low nutrient and organic mater contents. The bean crop is grown during the part of the year when rainfall is expected, but alternate wet and dry periods of varying lengths affect the production potential. Common beans have a relatively shallow rooting depth, poor nodulation, require frequent irrigations (Miller \& Gadner, 1972; Stansell \& Smitle, 1980; Weaver et al., 1984; Calvache \& Garcia, 1987) and large supplies of $\mathrm{N}$ fertilizers (Westerman et al., 1981; Calvache 1989; Castrillo et al., 1990). The increasing demands for limited water supplies and the rising costs of nitrogenous fertilizers lead to a rational use of these resources without adversely affecting production.

Cell expansion is one of the first growth processes affected by water stress. As a consequence, plants under severe stress are generally stunted. Leaf area, one of the main components of above-ground biomass, is also reduced by drought, due to reduced leaf area expansion and premature senescence (Salisbury \& Ross, 1992). This process acts as a survival tactic, reducing the rate of water use and delaying the onset of more severe stress, but is generally irreversible. However, given favorable conditions, plants with an indeterminate growth habit, like cowpeas and dry beans, may late compensate for this loss of leaf area by producing new leaves.

As observed by Castrillo et al., (1990) water deficit can result in a sudden decrease in nitrate redutase activity and fluctuations in ammonium content. Protein content may show significant decrease under deficit, folowed by an increase with addition of water. Under moderate water deficit, an initial protein degradation can take place, followed by protein synthesis at the expense of accumulated reduced nytrogen; leaf protein is probably used as a source of reduced nitrogen for new protein synthesis.

Water requirements of the common bean has received very litle attention in Ecuador and therefore, the purpose of this study was to identify specific growth stages of the common bean crop at which the plant is less sensitive to water stress and irrigation can be omitted without a significant decrease an final yield, and also to determine how irrigation deficits can affect fertilizer use efficiency .

\section{MATERIALS AND METHODS}

Two Field experiments were carried out at "La Tola" Agricultural Experimental Station in Tumbaco, Pichincha, Ecuador, on a Typic Haplustoll soil sandy loam texture $(16 \%$ clay; $0.8 \%$ organic matter and $\mathrm{pH} 6.8$ ). Seven waterstress treatments were tested at different growth stages (E1- vegetative; E2- flowering; E3Bean formation and E4- Ripening period), two levels of applied N-fertilizer $\left(F_{1}-20\right.$ and $F_{2}-80$ $\mathrm{kg} / \mathrm{ha} \mathrm{N}$ ) and two levels of irrigation: 1) Normal watering when real evapotranspiration was equal to the expected maximun (ETm); and 0) Deficit irrigation (aproximatly $=1 / 2 \mathrm{ETm}$ ).

These combinations resulted in 14 treatments shown in TABLE 1.

Physical and chemical characterization of the soil and neutron probe calibration (Greacen, 1981), were carried out before actual experimental work was iniciated. Bean seeds $v$. Imbabello were planted on July 3/1992 and July 2/1994. Plots of $33.6 \mathrm{~m}^{2}, 8$ furrows of $7 \mathrm{~m} \mathrm{(2}$ seeds per $25 \mathrm{~cm}$ ) were distributed in a split-plot design, with a plant population of $120,000 / \mathrm{ha}$. Irrigation treatments started after uniform germination and crop establishment (Doorenbos \& Kassan, 1979). Soil water content was measured with a neutron probe from 10 to $50 \mathrm{~cm}$ depth, before and $24 \mathrm{~h}$ after each irrigation, with measurements every $10 \mathrm{~cm}$. Soil matric potential was monitored by installing tensiometers at $0.20 \mathrm{~m} ; 0.40$ and $0.60 \mathrm{~m}$, between plants in a crop row.

The actual evapotranspiration (ETa) of the crop was estimated by the water-balance technique and drainage or upward flow from ground water was calculated by Darcy equation. Field water efficiency $\left(\mathrm{Ef}=\mathrm{kg} / \mathrm{m}^{3}\right)$ and crop water use efficiency $\mathrm{Ec}=\mathrm{kg} / \mathrm{m}^{3}$ ), were calculated dividing the actual grain yield ( $10 \%$ seed water content) y irrigation and by actual evapotranspiration (Eta), respectively (Doorenbos \& Pruit, 1977; Hillel, 1990). Samples of 4 plants were collected at diferent growth stages and 50 plants at the time of final harvest, to determine dry matter and nitrogen content in leaf and stem, dry weight of pods harvested, number of pods and harvest index. 
TABLE 1 - Treatment combinations.

\begin{tabular}{ccccccl}
\hline \multicolumn{7}{c}{ Growth Stage } \\
\hline No. & Treatments & 1 & 2 & 3 & 4 & Description \\
1 & F1 $\mathbb{R} 1$ & 1 & 1 & 1 & 1 & Normal watering \\
2 & F1 $\mathbb{R} 2$ & 0 & 0 & 0 & 0 & deficit irrigation \\
3 & F1 $\mathbb{R} 3$ &.. &.. &.. &.. & Traditional practice \\
4 & F1 $\mathbb{R} 4$ & 0 & 1 & 1 & 1 & stress at vegetation \\
5 & F1 $\mathbb{R} 5$ & 1 & 0 & 1 & 1 & Flowering \\
6 & F1 $\mathbb{R} 6$ & 1 & 1 & 0 & 1 & Yield formation \\
7 & F1 $\mathbb{R} 7$ & 1 & 1 & 1 & 0 & Ripening stages \\
8 & F2 $\mathbb{R} 1$ & 1 & 1 & 1 & 1 & Normal watering \\
9 & F2 $\mathbb{R} 2$ & 0 & 0 & 0 & 0 & deficit irrigation \\
10 & F2 IR3 &.. &.. &.. &.. & Traditional practice \\
11 & F2 IR4 & 0 & 1 & 1 & 1 & stress at vegetation \\
12 & F2 $\mathbb{R} 5$ & 1 & 0 & 1 & 1 & Flowering \\
13 & F2 $\mathbb{R} 6$ & 1 & 1 & 0 & 1 & Yield formation \\
14 & F2 $\mathbb{R} 7$ & 1 & 1 & 1 & 0 & Ripening stages \\
\hline
\end{tabular}

TABLE 2 - Physical Analysis and Moisture Calibration Curve of the Soil (BD = bulk density, $\mathrm{PD}=$ particle density, $\mathrm{A}=$ calibration intercept; $\mathrm{B}=$ calibration slope).

\begin{tabular}{ccccccccc}
\hline DEPTH $(\mathrm{cm})$ & $\begin{array}{l}\text { SAND } \\
(\%)\end{array}$ & $\begin{array}{l}\text { SILT } \\
(\%)\end{array}$ & $\begin{array}{l}\text { CLAY } \\
(\%)\end{array}$ & $\begin{array}{c}\text { BD } \\
\text { g.cm3 }\end{array}$ & $\begin{array}{c}\text { PD } \\
\text { g.cm3 }\end{array}$ & $\begin{array}{l}\text { Por. } \\
(\%)\end{array}$ & A & B \\
\hline $0-10$ & 70 & 16 & 14 & 1.4 & 2.65 & 52.8 & 0.089 & 0.16 \\
$10-28$ & 72 & 12 & 16 & 1.45 & 2.62 & 44.7 & +0.009 & 0.18 \\
$28-60$ & 54 & 20 & 26 & 1.36 & 2.51 & 45.8 & -0.05 & 0.21 \\
\hline
\end{tabular}

\section{RESULTS AND DISCUSSION}

The results of the physical analysis and the calibration of the neutron probe are shown in TABLE 2

TABLE 3 illustrates data of evapotranspiration calculated according to the modified Penman method and irrigation requirements for the treatment of normal watering (R1).

Deficit irrigation at different growth stages significantly influenced plants water evaporation and water balance (TABLES $4,5,6$, $7,8,9,10$ ). Drainage or upward flow from ground water was practically insignificant and did not cause significant error in the estimate of actual evapotranspiration (Eta).
TABLE 11 show soil water storages down to the $0,50 \mathrm{~m}$ depth during the two experimental periods. It can be seen that water content increases after an irrigation or rain, depending on the treatment. Water storage in the treatment of full stress (IR2) was lower than in the treatment of normal watering (IR1). Generally water storage in all the treatments was higher than that of the treatment of full stress (IR2) in the stages in which irrigation was made, but lower than in the treatment $\mathbb{R} 1$ which received irrigation during the entire cycle.

From the yield data presented in TABLES 12 and 13 it can be concluded that treatments which had irrigation deficit have lower yields than those that had supplementary 
migation (1\% probability). The flowering stage was the most sensitive to water stress. The treatment of stress at flowering stage (IR5) had the same result as the one which had water stress during the whole growing cycle (IR2), in the two experimental years (1992 and 1994). Comparing the results of fertiized treatments it can be seen that there are significant differences $(1 \%$ probability) between the two fertilization levels used in the two experimental years (1992 and
1994). The interaction between irrigation and fertilization was only statistically different in the second experimental year (1994). The highest value was obtained in the treatment IR4F2. It can also be seen that the lower yields correspond to treatments $\mathbb{I R} 5 \mathrm{~F} 2>\mathbb{R} 5 \mathrm{~F} 1>\mathbb{R} 2 \mathrm{~F} 2>\mathrm{R} 2 \mathrm{~F} 1$ which is the reflex of the fact that common bean requires frequent irrigations and soil matric potential of 10 to $-30 \mathrm{kPa}$ for optimum growth (Miller \& Gadner, 1972; Stansell \& Smitle, 1980).

TABLE 3 - Days after sowing (DAS), degrees-day (GD), crop coefficient (Kc), evapotranspiration (Eta), effective rainfall and irrigation needs for experimental conditions.

\begin{tabular}{lcccccc}
\hline Mês & DAS & $\mathrm{GD}_{\left(5^{\circ} \mathrm{C}\right)}$ & $\mathrm{Kc}$ & $\mathrm{ETc}$ & $\begin{array}{c}\text { Chuva efetiva } \\
\text { mm/década }\end{array}$ & Irrigação \\
\hline Jul & 10 & 106 & 0.35 & 16.0 & 0.2 & 15.7 \\
Jul & 20 & 212 & 0.35 & 16.1 & 0.0 & 16.1 \\
Jul & 30 & 318 & 0.38 & 18.0 & 0.5 & 17.5 \\
Aug & 40 & 424 & 0.54 & 26.8 & 1.0 & 25.8 \\
Aug & 50 & 530 & 0.80 & 41.8 & 1.5 & 40.3 \\
Aug & 60 & 636 & 1.04 & 52.2 & 4.5 & 47.7 \\
Setembro & 70 & 742 & 1.15 & 54.8 & 7.5 & 47.4 \\
Setembro & 80 & 848 & 1.15 & 52.9 & 10.4 & 42.5 \\
Setembro & 90 & 954 & 1.11 & 50.0 & 15.3 & 34.7 \\
Outubro & 100 & 1060 & 1.02 & 44.7 & 22.1 & 22.5 \\
Outubro & 110 & 1166 & 0.90 & 38.8 & 28.0 & 10.8 \\
Outubro & 120 & 1272 & 0.79 & 33.4 & 22.2 & 11.3 \\
Novembro & 130 & 1278 & 0.68 & 28.2 & 4.5 & 13.3 \\
TOTAL & 130 & 1378 & & 473.7 & 117.6 & 356.1 \\
\hline
\end{tabular}

A highly significant difference was found in seed yield as an effect of water treatments. Results presented in TABLE 13 show that the seed weigth of teatments IR2 and IR3 were the lowest. In common beans a loss of reproductive organs can occur even under the most favorable conditions; this loss can be of different magnitudes in the same cultivar, depending on the environmental conditions. In the present study the quantity of reproductive organs shed during the development of the crop under the different water treatments was not measured, however a major shed of flowers and young pods was observed in the water stress treatments (IR2, 
IR3, IR5). Without exception, the yield components were dimished by the stress treatments, and this decrease was more severe in IR6 with the reduction of numbers of pods per plant and weigth of 100 seeds.

Aspinal \& Paleg (1981) have enphatized that the organ wich is growing most rapidly at the time of the stress is the one most afected. For example, in the vegetive stage, the leaves and in rippening stage, the seeds. This relationship can actually lead to an increased harvest index (HI) under water stress because of strong reduction in vegetative growth. The treatment IR4 had HI of 0.59 , that is $18 \%$ over that of the control IR1. The nitrogen fertilization increased significantly the HI. Treatments F2 (80 kg N/ha) had HI $24 \%$ higer than of plants.F1, in accordance to Albrech et al., (1984) and Hedge \& Stinivas, (1990).
All stress treatments evaluated in this study reduced seed yield, however, as indicated, the highest reduction was found when the stress was imposed at the beginning of grain formation. This reduction in yield was due mainly to the reduction in the number of pods per plant. In this research, a small reduction in the number of seeds per pot and seed weigth was observed in treatments $\mathbb{R} 2$ and $\mathbb{R} 7$. The differences in yield among irrigation treatments could be attributed to the significant variations in the number of pods per plant. The improvement in yield with $\mathbf{N}$ fertilization was due to a significant increase in the number of pods per plants. Common bean being a poor nodulator, responds to the aplication of $\mathrm{N}$.

TABLE 4 - Water balance for irrigation regime 1 (IIII). (DAS = days after sowing); $A=$ water storage down to $0.50 \mathrm{~m} ; \mathrm{VA}=$ change of water storage; $\mathrm{P}=$ rainfall; $\mathrm{I}=$ irrigation; $\mathrm{D}=$ drainage or upward flow, $\mathrm{ETa}=$ actual evapotranspiration; ET ac $=$ accumulated evapotranspiration.

\begin{tabular}{|c|c|c|c|c|c|c|c|}
\hline \multirow[t]{2}{*}{ DAS } & $\mathbf{A}$ & VA & $\mathbf{P}$ & 1 & $\mathbf{D}$ & ETa & \multirow{2}{*}{$\frac{\text { ET ac }}{(\mathrm{mm})}$} \\
\hline & \multicolumn{2}{|l|}{$(\mathrm{mm})$} & \multicolumn{4}{|c|}{.......... (mm/day) } & \\
\hline 14 & 139.9 & & \multicolumn{3}{|c|}{30.0} & 1.6 & 22.4 \\
\hline 17 & 134.6 & -5.3 & 1.5 & 0.0 & -0.07 & 2.2 & 29.1 \\
\hline 26 & 134.5 & -0.1 & 0.0 & 25.0 & -0.19 & 2.8 & 54.0 \\
\hline 34 & 134.3 & -0.2 & 0.0 & 25.0 & -0.28 & 3.1 & 79.0 \\
\hline 40 & 139.6 & 5.3 & 2.3 & 25.0 & -0.80 & 3.5 & 100.2 \\
\hline 47 & 142.7 & 3.1 & 4.5 & 25.0 & -2.00 & 3.5 & 124.6 \\
\hline 53 & 140.1 & -2.6 & 0.0 & 25.0 & -1.97 & 4.3 & 150.2 \\
\hline 60 & 134.4 & -5.6 & 0.0 & 22.0 & -1.30 & 3.8 & 176.5 \\
\hline 68 & 122.5 & -12.0 & 0.0 & 30.0 & -0.28 & 5.2 & 218.2 \\
\hline 75 & 113.1 & -9.4 & 0.3 & 26.0 & -0.02 & 5.1 & 253.9 \\
\hline 82 & 129.7 & 16.6 & 30.7 & 26.0 & 0.01 & 5.7 & 294.0 \\
\hline 88 & 111.4 & -18.3 & 13.3 & 0.0 & 0.01 & 5.3 & 325.6 \\
\hline 96 & 131.4 & 20.0 & 37.5 & 13.0 & 0.01 & 3.8 & 356.1 \\
\hline 102 & 114.1 & -17.3 & 1.6 & 0.0 & 0.01 & 3.1 & 375.0 \\
\hline 109 & 107.4 & -6.8 & 0.0 & 18.0 & 0.00 & 3.5 & 399.7 \\
\hline 115 & 117.0 & 9.6 & 6.0 & 26.0 & 0.00 & 3.7 & 422.1 \\
\hline 122 & 126.4 & 9.4 & 13.2 & 22.0 & 0.01 & 3.7 & 447.9 \\
\hline \multicolumn{2}{|c|}{ TOTAL } & -13.5 & 110.9 & 338 & -6.86 & & \\
\hline
\end{tabular}


To compare the two experiments, TABLE 14 presents the final data for the variables: field water use efficiency (Ef), crop water use efficiency $(\mathrm{Ec})$ yield response factor (Ky) and relative yield response factor. Treatments IR1 and IR7 have more Ec than the other due to the higher productivity. Treatment IR2 has higher Ef due to the small quantity of applied irrigation water during the crop cycle. The $\mathrm{Ky}$ is higher in treatments $\mathbb{R} 2$ and $\mathbb{R} 5$, and lower in treatments IRI and IR7.
Water use of common bean was markedly influenced by the irrigation treatments. There was a decline in ETa with decreasing water content in the soil. This could be due to a combination of both, reduced surface soil evaporation with lower irrigation frequency and greater plant water deficits with low soil matric potentials. Water use efficiency, however, was maximun with deficit irrigation at the vegetative stage (IR4) and declined with irrigation frequency.

TABLE 5 - Water balance for irrigation regime $2(0000)$. (DAS $=$ days after sowing); $A=$ water storage down to $0.50 \mathrm{~m} ; \mathrm{VA}=$ change of water storage; $\mathrm{P}=$ rainfall; $\mathrm{I}=$ irrigation; $\mathrm{D}=$ drainage or upward flow, ETa = actual evapotranspiration; ET ac = accumulated evapotranspiration.

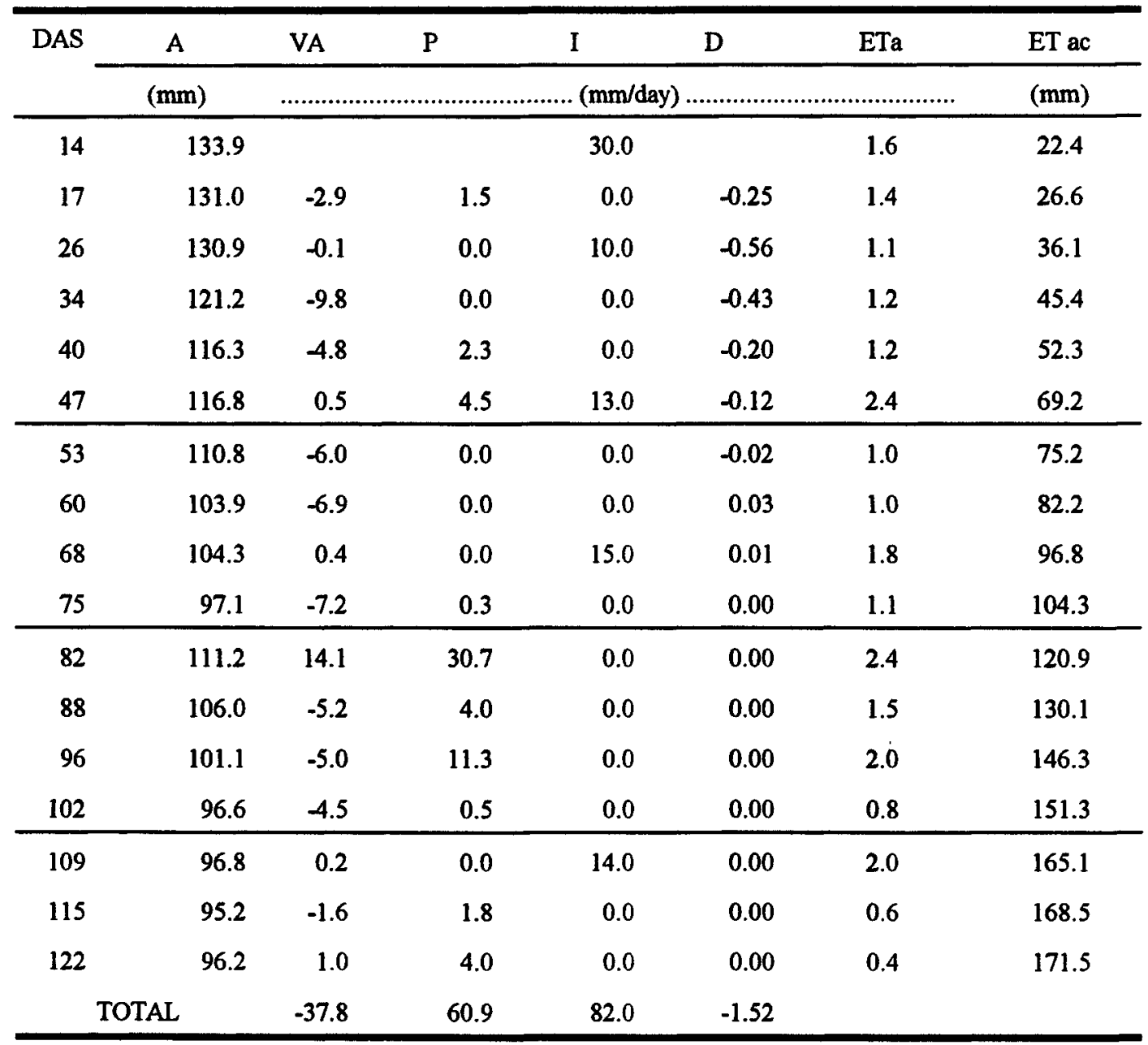


TABLE 6 - Water balance for irrigation regime 3 (RT). (DAS = days after sowing); $A=$ water storage down to $0.50 \mathrm{~m} ; \mathrm{VA}=$ change of water storage; $\mathrm{P}=$ rainfall; $\mathrm{I}=$ irrigation; $\mathrm{D}=$ drainage or upward flow, $\mathrm{ETa}=$ actual evapotranspiration; $\mathrm{ET}$ ac $=$ accumulated evapotranspiration.

\begin{tabular}{|c|c|c|c|c|c|c|c|}
\hline \multirow[t]{2}{*}{ DAS } & $A$ & VA & $\mathrm{P}$ & I & D & ETa & \multirow{2}{*}{$\frac{\mathrm{ET} \mathrm{ac}}{(\mathrm{mm})}$} \\
\hline & $(\mathrm{mm})$ & \multicolumn{5}{|c|}{ 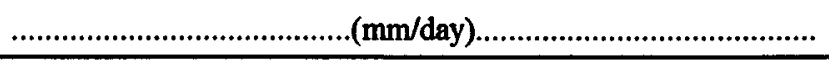 } & \\
\hline 14 & 135.8 & & & 30.0 & & 1.6 & 22.4 \\
\hline 17 & 129.7 & -6.1 & 1.5 & 0.0 & -0.02 & 2.5 & 30.0 \\
\hline 26 & 127.3 & -2.4 & 0.0 & 13.0 & -0.04 & 1.7 & 45.4 \\
\hline 34 & 124.1 & -3.2 & 0.0 & 13.0 & -0.03 & 2.0 & 61.5 \\
\hline 40 & 123.7 & -0.3 & 2.3 & 13.0 & -0.02 & 2.6 & 77.2 \\
\hline 47 & 122.1 & -1.7 & 4.5 & 13.0 & -0.02 & 2.7 & 96.3 \\
\hline 53 & 117.0 & -5.1 & 0.0 & 13.0 & -0.01 & 3.0 & 114.4 \\
\hline 60 & 114.1 & -2.9 & 0.0 & 11.0 & 0.00 & 2.0 & 128.3 \\
\hline 68 & 104.2 & -9.9 & 0.0 & 14.0 & 0.00 & 3.0 & 152.2 \\
\hline 75 & 101.4 & -2.8 & 0.3 & 15.0 & 0.00 & 2.6 & 170.2 \\
\hline 82 & 113.2 & 11.8 & 30.7 & 13.0 & 0.00 & 4.6 & 202.2 \\
\hline 88 & 106.8 & -6.4 & 13.3 & 0.0 & 0.00 & 3.3 & 221.9 \\
\hline 96 & 119.1 & 12.3 & 37.5 & 7.0 & 0.00 & 4.0 & 254.0 \\
\hline 102 & 108.6 & -10.6 & 1.6 & 0.0 & 0.00 & 2.0 & 266.2 \\
\hline 109 & 101.7 & -6.9 & 0.0 & 5.0 & 0.00 & 1.7 & 278.0 \\
\hline 115 & 106.2 & 4.5 & 6.0 & 13.0 & 0.00 & 2.4 & 292.6 \\
\hline 122 & 110.3 & 4.1 & 13.2 & 12.0 & 0.00 & 3.0 & 313.7 \\
\hline & & -25.5 & 110.9 & 185.0 & -0.14 & & \\
\hline
\end{tabular}


TABLE 7 - Water balance for irrigation regime 4 (OIII). (DAS = days after sowing); $A=$ water storage down to $0.50 \mathrm{~m} ; \mathrm{VA}=$ change of water storage; $\mathrm{P}=$ rainfall; $\mathrm{I}=$ irrigation; $\mathrm{D}=$ drainage or upward flow, $\mathrm{ETa}=$ actual evapotranspiration; ET ac $=$ accumulated evapotranspiration.

\begin{tabular}{|c|c|c|c|c|c|c|c|}
\hline \multirow[t]{2}{*}{ DAS } & $\mathbf{A}$ & VA & $\mathbf{P}$ & I & $\mathbf{D}$ & ETa & \multirow{2}{*}{$\frac{\mathrm{ET} \mathrm{ac}}{(\mathrm{mm})}$} \\
\hline & $(\mathrm{mm})$ & \multicolumn{5}{|c|}{ (mm/day) } & \\
\hline 14 & 136.4 & & & 30.0 & & 1.6 & 22.4 \\
\hline 17 & 130.7 & -5.7 & 1.5 & 0.0 & -0.01 & 2.4 & 29.6 \\
\hline 26 & 127.4 & -3.3 & 0.0 & 0.0 & -0.04 & 0.4 & 32.8 \\
\hline 34 & 121.4 & -6.0 & 0.0 & 0.0 & -0.02 & 0.7 & 38.8 \\
\hline 40 & 117.2 & -4.2 & 2.3 & 0.0 & 0.00 & 1.1 & 45.3 \\
\hline 47 & 113.5 & -3.7 & 4.5 & 6.0 & 0.03 & 2.0 & 59.6 \\
\hline 53 & 115.1 & 1.6 & 0.0 & 25.0 & 0.02 & 3.9 & 83.0 \\
\hline 60 & 117.4 & 2.3 & 0.0 & 22.0 & 0.03 & 2.8 & 102.7 \\
\hline 68 & 112.6 & -4.8 & 0.0 & 30.0 & 0.01 & 4.3 & 137.5 \\
\hline 75 & 107.8 & -4.8 & 0.3 & 26.0 & 0.00 & 4.4 & 168.6 \\
\hline 82 & 124.7 & 16.9 & 30.7 & 26.0 & 0.00 & 5.7 & 208.4 \\
\hline 88 & 112.9 & -11.8 & 13.3 & 0.0 & 0.00 & 4.2 & 233.5 \\
\hline 96 & 129.7 & 16.8 & 37.5 & 13.0 & 0.00 & 4.2 & 267.2 \\
\hline 102 & 115.9 & -13.8 & 1.6 & 0.0 & 0.00 & 2.6 & 282.6 \\
\hline 109 & 109.7 & -6.2 & 0.0 & 18.0 & 0.00 & 3.5 & 306.8 \\
\hline 115 & 116.6 & 6.9 & 6.0 & 26.0 & 0.00 & 4.2 & 331.9 \\
\hline 122 & 128.3 & 11.7 & 13.2 & 22.0 & 0.00 & 3.4 & 355.4 \\
\hline & & -8.1 & 110.9 & 244.0 & 0.02 & & \\
\hline
\end{tabular}


TABLE 8 - Water balance for irrigation regime 5 (IOII). (DAS = days after sowing); $A=$ water storage down to $0.50 \mathrm{~m} ; \mathrm{VA}=$ change of water storage; $P=$ rainfall; $I=$ irrigation; $D=$ drainage or upward flow; $\mathrm{ETa}=$ actual evapotranspiration; $\mathrm{ET}$ ac $=$ accumulated evapotranspiration.

\begin{tabular}{|c|c|c|c|c|c|c|c|}
\hline \multirow[t]{2}{*}{ DAS } & A & VA & $\mathbf{P}$ & I & D & ETa & \multirow{2}{*}{$\frac{\text { ET ac }}{(\mathrm{mm})}$} \\
\hline & $(\mathrm{mm})$ & \multicolumn{5}{|c|}{ (mm/day) } & \\
\hline 14 & 137.2 & & & 30.0 & & 1.6 & 22.4 \\
\hline 17 & 130.7 & -6.5 & 1.5 & 0.0 & -0.15 & 2.6 & 30.3 \\
\hline 26 & 129.0 & -1.8 & 0.0 & 25.0 & -0.35 & 2.9 & 56.7 \\
\hline 34 & 129.8 & 0.8 & 0.0 & 25.0 & -0.23 & 3.0 & 80.7 \\
\hline 40 & 131.4 & 1.6 & 2.3 & 25.0 & -0.10 & 4.3 & 106.2 \\
\hline 47 & 132.4 & 1.0 & 4.5 & 25.0 & -0.18 & 4.0 & 134.6 \\
\hline 53 & 118.2 & -14.2 & 0.0 & 0.0 & -0.23 & 2.3 & 148.5 \\
\hline 60 & 109.4 & -8.8 & 0.0 & 0.0 & -0.07 & 1.2 & 157.3 \\
\hline 68 & 104.0 & -5.4 & 0.0 & 0.0 & -0.01 & 0.7 & 162.7 \\
\hline 75 & 99.7 & -4.3 & 0.3 & 0.0 & 0.00 & 0.7 & 167.3 \\
\hline 82 & 118.8 & 19.1 & 30.7 & 25.0 & 0.00 & 5.2 & 203.9 \\
\hline 88 & 110.1 & -8.7 & 13.3 & 0.0 & 0.00 & 3.7 & 225.8 \\
\hline 96 & 129.1 & 19.0 & 37.5 & 13.0 & 0.00 & 3.9 & 257.3 \\
\hline 102 & 113.4 & -15.7 & 1.6 & 0.0 & 0.00 & 2.9 & 274.6 \\
\hline 109 & 106.2 & -7.3 & 0.0 & 18.0 & 0.00 & 3.6 & 299.9 \\
\hline 115 & 115.6 & 9.4 & 6.0 & 26.0 & 0.00 & 3.8 & 322.5 \\
\hline 122 & 124.9 & 9.3 & 13.2 & 22.0 & 0.00 & 3.7 & 348.4 \\
\hline & & -12.4 & 110.9 & 234.0 & -1.30 & & \\
\hline
\end{tabular}


TABLE 9 - Water balance for irrigation regime 6 (IIOI). (DAS = days after sowing); $A=$ water storage down to $0.50 \mathrm{~m} ; \mathrm{VA}=$ change of water storage; $\mathrm{P}=$ rainfall; $\mathrm{I}=$ irrigation; $\mathrm{D}=$ drainage or upward flow, Eta $=$ actual evapotranspiration; $\mathrm{Et}$ ac $=$ accumulated evapotrasnpiration.

\begin{tabular}{|c|c|c|c|c|c|c|c|}
\hline \multirow[t]{2}{*}{ DAS } & A & VA & $\mathrm{P}$ & I & D & \multirow{2}{*}{$\begin{array}{c}\text { ET } \\
(\mathrm{mm} / \text { day })\end{array}$} & \multirow{2}{*}{$\frac{\text { ET ac }}{(\mathrm{mm})}$} \\
\hline & \multicolumn{5}{|c|}{$(\mathrm{mm})$} & & \\
\hline 14 & 132.0 & & & 30.0 & & 1.6 & 22.4 \\
\hline 17 & 129.5 & -2.5 & 1.5 & 0.0 & -0.02 & 1.3 & 26.4 \\
\hline 26 & 125.8 & -3.6 & 0.0 & 25.0 & -0.02 & 3.2 & 55.0 \\
\hline 34 & 122.5 & -3.4 & 0.0 & 25.0 & -0.01 & 3.5 & 83.4 \\
\hline 40 & 128.5 & 6.1 & 2.3 & 25.0 & -0.01 & 3.5 & 104.6 \\
\hline 47 & 130.8 & 2.3 & 4.5 & 25.0 & -0.02 & 3.9 & 131.8 \\
\hline 53 & 123.0 & -7.8 & 0.0 & 25.0 & -0.01 & 5.5 & 164.6 \\
\hline 60 & 119.7 & -3.3 & 0.0 & 22.0 & -0.01 & 3.6 & 189.9 \\
\hline 68 & 112.9 & -6.8 & 0.0 & 30.0 & 0.00 & 4.6 & 226.7 \\
\hline 75 & 100.1 & -12.9 & 0.3 & 15.0 & 0.00 & 4.0 & 254.8 \\
\hline 82 & 106.3 & 6.2 & 30.7 & 0.0 & 0.00 & 3.5 & 279.3 \\
\hline 88 & 103.5 & -2.8 & 4.0 & 0.0 & 0.00 & 1.1 & 286.1 \\
\hline 96 & 102.4 & -1.2 & 11.3 & 0.0 & 0.00 & 1.6 & 298.5 \\
\hline 102 & 98.0 & -4.4 & 0.5 & 0.0 & 0.00 & 0.8 & 303.4 \\
\hline 109 & 103.0 & 5.0 & 0.0 & 30.0 & 0.00 & 3.6 & 328.4 \\
\hline 115 & 110.9 & 7.9 & 6.0 & 26.0 & 0.00 & 4.0 & 352.5 \\
\hline 122 & 125.4 & 14.5 & 13.2 & 22.0 & 0.00 & 3.0 & 373.2 \\
\hline \multicolumn{2}{|c|}{ TOTAL } & -6.6 & 74.3 & 300.0 & -0.09 & & \\
\hline
\end{tabular}


TABLE 10 - Water balance for irrigation regime 7 (III0). (DAS = days after sowing); $A=$ water storage down to $0.50 \mathrm{~m} ; \mathrm{VA}=$ change of water storage; $\mathrm{P}=$ rainfall; $\mathrm{I}=$ irrigation; $\mathrm{D}=$ drainage or upward flow, ETa = actual evapotranspiration; ET ac = accumulated evapotranspiration.

\begin{tabular}{|c|c|c|c|c|c|c|c|}
\hline \multirow[t]{2}{*}{ DAS } & A & VA & $\mathbf{P}$ & I & D & ETa & \multirow{2}{*}{$\begin{array}{l}\text { ET ac } \\
(\mathrm{mm})\end{array}$} \\
\hline & $(\mathrm{mm})$ & \multicolumn{5}{|c|}{ 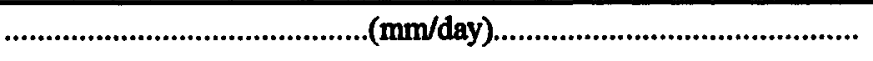 } & \\
\hline 14 & 135.3 & & & 30.0 & & 1.6 & 22.4 \\
\hline 17 & 130.7 & -4.6 & 1.5 & 0.0 & -0.12 & 2.0 & 28.4 \\
\hline 26 & 129.3 & -1.4 & 0.0 & 25.0 & -0.21 & 2.9 & 54.5 \\
\hline 34 & 126.8 & -2.6 & 0.0 & 25.0 & -0.01 & 3.4 & 82.1 \\
\hline 40 & 142.3 & 15.6 & 2.3 & 25.0 & -0.03 & 2.0 & 93.8 \\
\hline 47 & 138.8 & -3.5 & 4.5 & 25.0 & -0.40 & 4.7 & 126.4 \\
\hline 53 & 128.0 & -10.8 & 0.0 & 25.0 & -0.39 & 5.9 & 161.8 \\
\hline 60 & 126.1 & -1.9 & 0.0 & 22.0 & -0.34 & 3.4 & 185.4 \\
\hline 68 & 116.3 & -9.9 & 0.0 & 30.0 & -0.08 & 5.0 & 225.2 \\
\hline 75 & 110.5 & -5.7 & 0.3 & 26.0 & -0.09 & 4.6 & 257.1 \\
\hline 82 & 125.5 & 15.0 & 30.7 & 26.0 & 0.01 & 6.0 & 298.8 \\
\hline 88 & 110.2 & -15.3 & 13.3 & 0.0 & 0.01 & 4.8 & 327.4 \\
\hline 96 & 124.6 & 14.4 & 37.5 & 13.0 & 0.01 & 4.5 & 363.5 \\
\hline 102 & 108.1 & -16.5 & 0.5 & 0.0 & 0.00 & 2.8 & 380.5 \\
\hline 109 & 98.1 & -10.1 & 0.0 & 0.0 & 0.00 & 1.4 & 390.6 \\
\hline 115 & 94.7 & -3.4 & 1.8 & 0.0 & 0.00 & 0.9 & 395.8 \\
\hline 122 & 96.1 & 1.4 & 4.0 & 0.0 & 0.00 & 0.4 & 398.4 \\
\hline & CAL & -39.2 & 96.4 & 272.0 & -1.63 & & \\
\hline
\end{tabular}


TABLE 11 - Water storage $(\mathrm{mm}) 0$ to $0.50 \mathrm{~m}$ depth DAS= days after sowing.

\begin{tabular}{|c|c|c|c|c|c|c|c|}
\hline \multicolumn{8}{|c|}{1992} \\
\hline DAS & $\mathbf{R} \mathbf{I}$ & $\mathbb{R} 2$ & IR3 & IR4 & IR5 & IR6 & IR7 \\
\hline 20 & 95 & 96 & 104 & 89 & 95 & 97 & 99 \\
\hline 25 & 90 & 97 & 97 & 86 & 88 & 89 & 88 \\
\hline 32 & 93 & 95 & 98 & 87 & 90 & 93 & 92 \\
\hline 39 & 112 & 97 & 106 & 106 & 103 & 98 & 101 \\
\hline 43 & 118 & 89 & 114 & 101 & 110 & 101 & 105 \\
\hline 46 & 128 & 97 & 121 & 100 & 122 & 110 & 120 \\
\hline 53 & 114 & 90 & 104 & 95 & 106 & 105 & 104 \\
\hline 60 & 108 & 90 & 93 & 90 & 95 & 100 & 99 \\
\hline 67 & 112 & 92 & 90 & 93 & 93 & 96 & 101 \\
\hline 74 & 121 & 97 & 104 & 108 & 103 & 101 & 121 \\
\hline 81 & 109 & 92 & 94 & 98 & 99 & 92 & 107 \\
\hline 88 & 122 & 94 & 104 & 105 & 106 & 92 & 116 \\
\hline 95 & 115 & 87 & 99 & 100 & 107 & 87 & 107 \\
\hline 102 & 150 & 103 & 147 & 151 & 142 & 135 & 112 \\
\hline 109 & 119 & 102 & 114 & 128 & 115 & 112 & 108 \\
\hline \multicolumn{8}{|c|}{1994} \\
\hline 17 & 135 & 131 & 130 & 131 & 131 & 129 & 131 \\
\hline 26 & 135 & 131 & 127 & 127 & 129 & 126 & 129 \\
\hline 34 & 134 & 121 & 124 & 121 & 130 & 122 & 127 \\
\hline 40 & 140 & 116 & 124 & 117 & 131 & 128 & 142 \\
\hline 47 & 143 & 117 & 122 & 113 & 132 & 130 & 139 \\
\hline 53 & 140 & 111 & 117 & 115 & 118 & 123 & 128 \\
\hline 60 & 144 & 103 & 114 & 117 & 109 & 120 & 126 \\
\hline 68 & 132 & 104 & 104 & 113 & 104 & 113 & 116 \\
\hline 75 & 123 & 97 & 101 & 108 & 100 & 100 & 111 \\
\hline 82 & 140 & 117 & 113 & 125 & 119 & 106 & 126 \\
\hline 88 & 121 & 124 & 107 & 113 & 110 & 110 & 110 \\
\hline 96 & 141 & 101 & 119 & 130 & 129 & 102 & 125 \\
\hline 102 & 124 & 97 & 109 & 116 & 113 & 98 & 108 \\
\hline 109 & 117 & 97 & 102 & 110 & 106 & 103 & 98 \\
\hline 115 & 127 & 95 & 106 & 116 & 116 & 111 & 95 \\
\hline 122 & 136 & 96 & 110 & 128 & 126 & 125 & 96 \\
\hline
\end{tabular}


TABLE 12 - Yield components as a function of treatments (1992).

\begin{tabular}{|c|c|c|c|}
\hline FACTORS & Yield (Kg/ha) & $\mathrm{N}^{\circ}$ of pods/plant & Harvest index \\
\hline Irrigation & $(* *)$ & $(* *)$ & $(* *)$ \\
\hline II & $2627 a$ & $15 a b+$ & $0.55 \mathrm{~b}$ \\
\hline 12 & $1164 \mathrm{c}$ & $10 \mathrm{c}$ & $0.52 \mathrm{~b}$ \\
\hline 13 & $2264 a b$ & $14 a b c$ & $0.59 \mathrm{ab}$ \\
\hline I4 & $2462 a b$ & $14 a b c$ & $0.65 \mathrm{a}$ \\
\hline IS & $1775 \mathrm{bc}$ & $11 \mathrm{bc}$ & $0.55 \mathrm{~b}$ \\
\hline I6 & $2146 \mathrm{abc}$ & $13 a b c$ & $0.56 \mathrm{~b}$ \\
\hline 17 & $2453 a b$ & $17 \mathrm{a}$ & $0.55 \mathrm{~b}$ \\
\hline Fertilization & $(* *)$ & $(* *)$ & $(* *)$ \\
\hline F1 & 1994 b & $13 \mathrm{~b}$ & $0.51 \mathrm{~b}$ \\
\hline F2 & $2260 a$ & $14 a$ & $0.62 \mathrm{a}$ \\
\hline Interactions & (ns) & (ns) & $(*)$ \\
\hline IIF1 & 2240 & 14 bcde & 0.44 ef \\
\hline IIF2 & 3015 & $17 a b$ & $0.66 \mathrm{ab}$ \\
\hline I2F1 & 1267 & $10 \mathrm{ef}$ & $0.39 \mathrm{f}$ \\
\hline $\mathrm{I2F} 2$ & 1060 & $9 \mathrm{f}$ & $0.66 \mathrm{ab}$ \\
\hline I3F1 & 2153 & 14 bcde & $0.58 b c$ \\
\hline I3F2 & 2376 & 14 bade & $0.60 \mathrm{bc}$ \\
\hline I4F1 & 2294 & 13 bcde & $0.56 \mathrm{bc}$ \\
\hline $\mathrm{I} 4 \mathrm{~F} 2$ & 2631 & 15 abcd & $0.74 \mathrm{a}$ \\
\hline $15 F 1$ & 1754 & $11 \mathrm{ef}$ & $0.45 e$ \\
\hline I5F2 & 1796 & $11 \mathrm{ef}$ & $0.64 \mathrm{abc}$ \\
\hline 16F1 & 1969 & 12 cde & $0.57 \mathrm{bc}$ \\
\hline I6F2 & 2324 & 14 bcde & $0.55 \mathrm{c}$ \\
\hline ITF1 & 2158 & 16 abcd & $0.57 b c$ \\
\hline I7F2 & 2620 & $19 a$ & $0.54 \mathrm{~d}$ \\
\hline CV (\%) & 15 & 12 & 17 \\
\hline
\end{tabular}

ns $=$ non significant $-\mathrm{F}$ test

* = significant at $5 \%$ level $-F$ test

** = highly significant at $5 \%$ level $-\mathrm{F}$ test

$+=$ averages followed by different letter in the same column differ statistically at $p<0,05$ 
TABLE 13 - Yield components as a function of treatments (1994).

\begin{tabular}{|c|c|c|c|c|c|c|}
\hline \multicolumn{2}{|c|}{ Factors } & Yield & $\begin{array}{c}\mathrm{N}^{\circ} \text { of } \\
\text { pods/plant }\end{array}$ & $\begin{array}{c}\mathrm{N}^{\circ} \text { of } \\
\text { grains/pod }\end{array}$ & $\begin{array}{c}\text { Mass of } \\
100 \text { grains (g) }\end{array}$ & $\begin{array}{c}\text { Harvest } \\
\text { index }\end{array}$ \\
\hline \multicolumn{2}{|l|}{ Irrigation } & $* *$ & $*$ & $* *$ & $* *$ & $* *$ \\
\hline \multicolumn{2}{|l|}{ R1 } & $2974.30 \mathrm{a}$ & $23.08 \mathrm{a}$ & $4.43 \mathrm{a}$ & $51.72 a b$ & $0.50 \mathrm{~b}$ \\
\hline \multicolumn{2}{|l|}{ R2 } & $1285.58 \mathrm{~d}$ & $15.58 \mathrm{~d}$ & $4.32 \mathrm{a}$ & $49.04 \mathrm{c}$ & $0.47 \mathrm{~b}$ \\
\hline \multicolumn{2}{|l|}{ R3 } & $2494.83 \mathrm{ab}$ & $18.18 \mathrm{c}$ & $4.40 \mathrm{a}$ & $49.81 \mathrm{bc}$ & $0.54 \mathrm{ab}$ \\
\hline \multicolumn{2}{|l|}{ R4 } & 2990.78 a & $22.60 \mathrm{a}$ & $4.47 \mathrm{a}$ & 53.85 a & $0.59 \mathrm{a}$ \\
\hline \multicolumn{2}{|l|}{ R5 } & $2302.20 \mathrm{bc}$ & $19.01 \mathrm{bc}$ & $4.41 \mathrm{a}$ & $51.69 \mathrm{ab}$ & $0.50 \mathrm{~b}$ \\
\hline \multicolumn{2}{|l|}{ R6 } & $1910.17 \mathrm{c}$ & $20.48 \mathrm{~b}$ & $4.41 \mathrm{a}$ & $51.37 \mathrm{bc}$ & $0.51 \mathrm{~b}$ \\
\hline \multicolumn{2}{|l|}{ R7 } & $2301.06 \mathrm{bc}$ & $23.50 \mathrm{a}$ & $3.87 \mathrm{~b}$ & $44.76 \mathrm{~d}$ & $0.51 \mathrm{~b}$ \\
\hline \multicolumn{2}{|l|}{ Fertilization } & $* *$ & $* *$ & $* *$ & NS & ** \\
\hline \multicolumn{2}{|l|}{ F1 } & $2088.77 b$ & $19.33 \mathrm{~b}$ & $4.27 \mathrm{~b}$ & 50.47 & $0.46 \mathrm{~b}$ \\
\hline \multicolumn{2}{|l|}{ F2 } & $2556.62 \mathrm{a}$ & $21.36 \mathrm{a}$ & $4.39 \mathrm{a}$ & 50.17 & $0.57 \mathrm{a}$ \\
\hline \multicolumn{2}{|l|}{ Interactions } & * & $*$ & NS & MS & $* *$ \\
\hline R1 & F1 & $2711.22 \mathrm{bcd}$ & $22.10 \mathrm{bc}$ & 4.45 & 52.33 & 0.40 ef \\
\hline Rl & F2 & $3237.30 \mathrm{ab}$ & $24.05 \mathrm{ab}$ & 4.40 & 51.10 & $0.60 \mathrm{ab}$ \\
\hline $\mathbf{R 2}$ & F1 & $1058.35 \mathrm{~h}$ & $15.48 \mathrm{~g}$ & 4.12 & 49.65 & $0.35 \mathrm{f}$ \\
\hline $\mathbf{R} 2$ & F2 & $1512.80 \mathrm{gh}$ & $15.68 \mathrm{~g}$ & 4.53 & 48.42 & $0.60 \mathrm{abc}$ \\
\hline R3 & F1 & 2090.55 ef & $16.83 \mathrm{fg}$ & 4.28 & 50.18 & $0.53 \mathrm{bcd}$ \\
\hline $\mathbf{R} 3$ & F2 & $2899.11 \mathrm{abc}$ & 19.53 cdef & 4.51 & 49.44 & $0.55 \mathrm{bcd}$ \\
\hline R4 & F1 & $2677.28 \mathrm{~cd}$ & 21.53 bcde & 4.47 & 52.88 & $0.51 \mathrm{bcd}$ \\
\hline R4 & F2 & $3304.28 \mathrm{a}$ & $23.68 \mathrm{ab}$ & 4.48 & 54.82 & $0.68 \mathrm{a}$ \\
\hline R5 & $\mathrm{F} 1$ & $2085.40 \mathrm{f}$ & 18.78 ef & 4.40 & 51.50 & 0.41 ef \\
\hline R5 & F2 & 2518.98 cde & 19.25 def & 4.43 & 51.88 & $0.59 \mathrm{abcd}$ \\
\hline R6 & F1 & $1734.20 \mathrm{fg}$ & 18.88 ef & 4.33 & 51.68 & $0.52 \mathrm{bcd}$ \\
\hline R6 & F2 & 2086.15 ef & $22.08 \mathrm{bc}$ & 4.50 & 51.06 & $0.50 \mathrm{cde}$ \\
\hline R7 & F1 & 2264.36 def & 21.75 bcd & 3.89 & 45.05 & $0.52 \mathrm{bcd}$ \\
\hline R7 & F2 & $2337.76 \mathrm{de}$ & $25.25 \mathrm{a}$ & 3.86 & 44.48 & $0.49 \mathrm{de}$ \\
\hline & $\mathrm{CV}(\%)$ & 8.5 & 4.62 & 3.98 & 2.99 & 8.49 \\
\hline
\end{tabular}

ns $=$ non significant $-\mathrm{F}$ test

$*=$ significant at $5 \%$ level $-F$ test

$* *$ = highly significant at $5 \%$ level $-F$ test

$+=$ averages followed by different letter in the same column differ statistically at $p<0.05$ 
TABLE 14 - Field water efficiency $\left(\mathrm{Ef}=\mathrm{Kg} / \mathrm{m}^{3}\right)$, Actual Evapotranspira-tion (Eta $=\mathrm{mm}$ ), Crop Water Use Efficiency $\left(E c=k g / \mathrm{m}^{3}\right)$, Relative Evaporation Deficit $(\mathrm{Ky})$, at fertilization level F1.

\begin{tabular}{llllllll}
\hline & \multicolumn{7}{c}{1992} \\
\hline Treat & Ef & ETa & Ec & 1-ETa/ETm & $1-Y a / Y m$ & KY & $\begin{array}{l}\text { Ky } \\
\text { relative }\end{array}$ \\
I1 & 0.60 & 355 & 0.63 & 0.00 & 0.00 & - & - \\
I2 & 0.61 & 222 & 0.57 & 0.37 & 0.43 & 1.16 & 1.00 \\
I3 & 0.72 & 314 & 0.69 & 0.12 & 0.04 & 0.34 & 0.29 \\
I4 & 0.71 & 316 & 0.73 & 0.11 & 0.00 & 0.00 & 0.00 \\
I5 & 0.56 & 321 & 0.55 & 0.10 & 0.22 & 2.27 & 1.95 \\
I6 & 0.64 & 309 & 0.64 & 0.13 & 0.12 & 0.93 & 0.80 \\
I7 & 0.94 & 340 & 0.63 & 0.04 & 0.04 & 0.87 & 0.75 \\
\hline & & & & 1994 & & & \\
\hline I1 & 0.60 & 448 & 0.61 & 0.00 & 0.00 & - & - \\
I2 & 0.74 & 172 & 0.62 & 0.62 & 0.61 & 0.99 & 1.00 \\
I3 & 0.71 & 314 & 0.67 & 0.30 & 0.23 & 0.76 & 0.77 \\
I4 & 0.75 & 356 & 0.75 & 0.21 & 0.01 & 0.06 & 0.06 \\
I5 & 0.60 & 348 & 0.60 & 0.22 & 0.23 & 1.04 & 1.05 \\
I6 & 0.46 & 373 & 0.46 & 0.17 & 0.36 & 2.16 & 2.18 \\
I7 & 0.61 & 398 & 0.57 & 0.11 & 0.16 & 1.49 & 1.51 \\
\hline
\end{tabular}

Relation to the traditional practice adopted by farmers of the region, only treatments IR1 and IR7 had 13 and $10 \%$ higher crop water use efficiency. The relative evaporation deficit (Ky) was lowest at the $\mathbb{R} 4$ and higher at $\mathbb{R} 5$ treatments.

\section{CONCLUSIONS}

Crop water use efficiency was the lowest at the flowering period and the yield reponse factor (Ky) was higher in treatment $\mathbb{I} 2$ and IR 5. The flowering stage was the most sensitive to moisture stress. Nitrogen fertilization significantly increased the number of pods and grain yield.

\section{REFERENCES}

ACOSTA-GALLEGOS, J.A; SHIBATA, J.K. Effects of water stress on growth and yield of indeterminate dry bean (Phaseolus vulgaris L.) cultivars. Field Crop Research, v.20, p.81-93, 1989.
ACOSTA-GALLEGOS, J.A; ADAMS, M.W. Plant traits and yield stability of dry bean (Phaseolus vulgaris L.) cultivar under drought stress. Joumal of Agriculture Sclence, v.117, p.213-219, 1991.

LBRECHT. S.L.; BENNET, J.M.; BOTE, K.J. Relationship on nitrogenase activity to plant water stress in field grown soybean. Field Crop Research, v.8, p.61-71, 1984 .

ASPINALL, D.; PALEG, L.G. The physiology and blochemistry of drought resistance in plants. New York: Academic Press, 1981. p.205-241: Proline accumulation: physiological aspects.

BONANO, A.R; MACK, M.J. Yield components and pod quality of snapbeans grown under differential irrigation. Joumal of the American Society for Horticultural Science, v.105, p.869-863, 1983.

CALVACHE, M. Eficiencia de la fijación biológica de nitrógeno en frijol y haba, utilizando ${ }^{15} \mathrm{~N}$ y 2 cultivos de referencia, en Tumbaco - Pichincha. Rumipamba, v.6, p.1-10, 1989. 
CALVACHE, M.; GARCIA C. Dinámica del agua en un cultivo de frijol (Phaseolus vulgaris). Rumipamba, v.4, p.1-18, 1987.

CALVACHE, M.; PORTEZAN, O.; SILVA, J.; REICHARDT, K. Conductividade hidráulica de um solo Typic Haplustoll em condiçóes de campo. In: CONGRESSO BRASILEIRO DE CIÊNCIA DO SOLO, 25., Viçosa, 1995. Resumos Expandidos. Viçosa: SBCS, 1995a. p.63-65.

CASTRILLO, M.; FERNANDEZ, D.; FERNANDEZ, P.; MOLINA, B.; KAZANDJIAN, A Metabolismo del nitrógeno en Phaseolus vulgaris L. bajo déficit hídrico. Turrialba, v.40, n.4, p.515-519, 1990.

DOORENBOS, J.; KASSAN, A.H. Yield response to water. Rome: FAO, 1979. 193p. (FAO. Irrigation and Drainage Paper, 33).

DOORENBOS, J.; PRUTTT, W.O. Guidelines for predicting crop water requirements. Rome: FAO, 1977. 179p. (FAO. Irrigation and Drainage Paper, 24).

GREACEN, E.L. Soll water assessment by the neutron method. Adelaide: CSIRO, 1981. 140p.

HEDGE, D.M.; SRINIVAS, K. Plant water relations and nutrient uptake in French bean. Imigation Science, v.11, p.51-56, 1990.

HENDRICKX, J.M.H.; WIERENGA, P.J.; NASH, M.S. Variability of soil water tension and soil water content. Agricultural Water Management, v.18, p.135-141, 1990.

HILLEL, D. Applications of soil physics. London: Academic Press, 1980. 385p.

HILLEL, D. Role of irrigation in agricultural systems. In: STEWART, B.A.; NIELSEN, D.R., ed. Irrigation of agricultural crops. Madison: ASA, 1990. cap.2, p.5-20.

MILLAR A.A.; GARDNER W.R. Effect of soil and plant water potentials on the dry matter production of snap beans. Agronomy Journal, v.64, p.559-562, 1972
PASSIOURA, J.B. Roots and drought resistance. Agriculture Water Managemewnt, v.7, p.265-280, 1983.

REICHARDT, K.; BACCHI, O.O.S.; VILLAGRA, M.M.; TURATTI, A.L.; PEDROSA, O.Z. Hydraulic variability in space and time in a dark red latosol of the tropics. Geoderma, v.60, p.159-168, 1993.

REICHARDT, K.; LIBARDI, P.L.; SANTOS, J.M. dos. An analysis of soil-water movement in the field: II, water balance in a snap bean crop. Piracicaba: CENAJUSP, 1974. 19p. (CENA. Boletim Cientifico, 22).

REICHARDT, K.; LIBARDI, P.L.; MORAES, S.O.; BACCHI, O.O.S.; TURATTI, AL.; VILLAGRA, M.M. Soil spatial variability and its implications on the establishment of water balances. In: CONGRESSO INTERNACIONAL DE CIÊNCIA DO SOLO, 14., Kioto, 1990. Anais. Kioto: Sociedade Internacional de Cilncia do Solo, 1990. p.41-46.

STANSELL, J.R.; SMITTLE, D.A. Effects of irrigation regimes on yield and water use of Snap Bean (Phaseolus vulgaris L.). Journal of the America Society for Horticultural Science, v.105, n.6, p.869-873, 1980.

WEAVER, M.L.; Ng H.; BURKE, D.W.; SILBERNAGEL, N.J.; FOSTER, K; TIMM, H. Effect of soil moisture tension on pos retention and seed yield of bean. Horticultural Sclence, v.19, p.567-572, 1984.

WESTERMAN, D.T.; G.E. KLENNOPF; L.K. PORTER; LOGGET, G.E. Nitrogen sources for bean seed production. Agronomy Joumal, v.73, p.660-664, 1981.

WHITE, J.; MOLANO, C.H. Production of common bean under saturated soil culture. Field Crop Research, v.36, p.53-58, 1994.

Recebido para publicação em 01.04 .97

Aceito para publicação em 15.04 .97 